\title{
PUBLIC SERVICE PERFORMANCE IN THE LAND OFFICE OF PANGKALPINANG CITY
}

\section{Rony Kurniawan}

Terbuka University

E-mail: dd_arema@yahoo.co.id

\begin{tabular}{|c|c|}
\hline ARTICLE INFO & ABSTRACT \\
\hline $\begin{array}{l}\text { Received: } \\
\text { July, 24 }{ }^{\text {th }} 2021 \\
\text { Revised: } \\
\text { August, 17th } 2021 \\
\text { Approved: } \\
\text { August, 19th } 2021\end{array}$ & $\begin{array}{l}\text { This research's background was the assumptions that services } \\
\text { in the land sector are still too difficult and convoluted. This } \\
\text { study's problems are how the performance of the Land Office } \\
\text { of Pangkalpinang in providing service and the supporting and } \\
\text { restraining factors. This research is a descriptive study with a } \\
\text { qualitative approach. Collecting data through in-depth } \\
\text { interviews, observation and documentation. The data were } \\
\text { gathered from } 15 \text { employees who were the sample in this } \\
\text { study. The results bring a conclusion that the performance of } \\
\text { the Land Office of Pangkalpinang has generally been running } \\
\text { well and fulfilling the public's expectations. The indicators are } \\
\text { (a) Effectiveness, (b) Responsiveness, in recognizing and } \\
\text { knowing the public's needs, and (c) Accountability, on doing } \\
\text { their duties and functions that followed the organizational } \\
\text { vision and mission. Internal and external factors that } \\
\text { influence the performance are (a) The ability of employees, } \\
\text { an internal factor, (b) Motivation, (c) Public participation, an } \\
\text { external factor that is inadequate in supporting office } \\
\text { performance; (d) Communication factors. }\end{array}$ \\
\hline KEYWORDS & effectiveness, responsiveness, accountability \\
\hline (c) (i) (-) & $\begin{array}{l}\text { This work is licensed under a Creative Co } \\
\text { Attribution-ShareAlike } 4.0 \text { International License }\end{array}$ \\
\hline
\end{tabular}

\section{INTRODUCTION}

In Pangkalpinang City, the number of plots of land currently available is

\begin{tabular}{ll}
\hline & Rony Kurniawan. (2021) Public Service Performance in the Land Office of \\
& Pangkalpinang City. Journal Eduvest. 1(8): 794-802 \\
How to cite: & $2775-3727$ \\
E-ISSN: & https://greenpublisher.co.id/ \\
Published by: &
\end{tabular}




\section{Rony Kurniawan}

approximately 55,000, of which approximately 35,000 are registered or certified. Unfortunately, the rest have not been registered. The Pangkalpinang City Land Office has to carry out land registration activities, whether carried out systematically through PRONA (National Agrarian Program) activities funded by the state or carried out sporadically by the community themselves (Adolf, 2017).

As many lands have not been recorded, and there are still public complaints about services at the Pangkalpinang City Land Office, the office should make information about the organizational performance, and the public deserves to know about it because the office is an essential public organization (Maharani, 2021). That is because public services are in the public spotlight because of the stigma that arises if public services are still complicated, with no transparency of costs and the duration of completion (Afriani, 2018).

Therefore, the Land Office as an agency that carries out administrative policies in the land sector must be ready to serve all the needs. The question that then arises is how the actual performance of the Pangkalpinang City Land Office as a public service institution. Of course, conducting experiments with several things, both internal and external, resulted in organizational performance not being able to run properly.

Several previous studies have discussed the performance of a public organization with emphasis from a different point of view, such as:

1. Thesis (Sukowati, 2010) entitled Organizational Performance of the Kedawung District Office, Sragen Regency, where the conclusions of this study indicate that the organizational performance at the Kedawung District Office is not following the expectations of the community.

2. Thesis (Juniati, 2012) namely Analysis of Archives Management Performance of the Denpasar City Archives and Documentation Library Board whereby improving archival facilities and facilities more fully by placing more strategic locations and easily accessible by other SKPD as users,

3. Thesis (Kurniati, 2012) on the Analysis of Public Service Performance of Government Apparatus at the Labuhan Badas Sub-District Office, Labuhan Badas District, Sumbawa Regency, West Nusa Tenggara Province shows that the performance of the apparatus, in general, can be said quite good, it was based on the indicators of responsiveness, effectiveness, efficiency, and fairness, while internal leadership factors, work motivation, and employee intelligence also influence organizational performance..

From several previous studies, it can be seen that the concept of performance can basically be seen from two aspects: employee performance (individually) and organizational performance (Wijayanto, 2011). There are indicators of an organization's assessment in previous studies, such as efficiency, effectiveness, fairness, responsiveness, and others.

The purpose of the implementation of this research is to analyze the performance of the Land Office of Pangkalpinang City in carrying out service tasks to the community and also to analyze what factors are inhibiting and supporting the performance of the employees of the Land Office of Pangkalpinang City.

\section{RESEARCH METHODS}

The present study used the descriptive qualitative research method (descriptive research), which is intended to be the attentive measurement of certain social phenomena. Singarimbun \& Effendi (1989) mention that descriptive research is intended to develop concepts and collect facts, but it does not test hypotheses. The implementation of 
descriptive research methods is not limited to collecting and compiling data but includes analysis and interpretation of the meaning of the data. Besides that, everything that is collected is likely to be the key to what is being studied. In accordance with this, to determine the performance of the Pangkalpinang City Land Office, the authors use qualitative descriptive research methods.

\section{RESULTS AND DISCUSSION}

\section{A. Overview of the Pangkalpinang City Land Office}

The Pangkalpinang City Land Office is a vertical agency of the National Land Agency located in the city, so it is responsible to the Head of the National Land Agency through the Head of the Regional Office of the National Land Agency of the Bangka Belitung Islands Province. The organizational structure of the Pangkalpinang City Land Office is as follows:

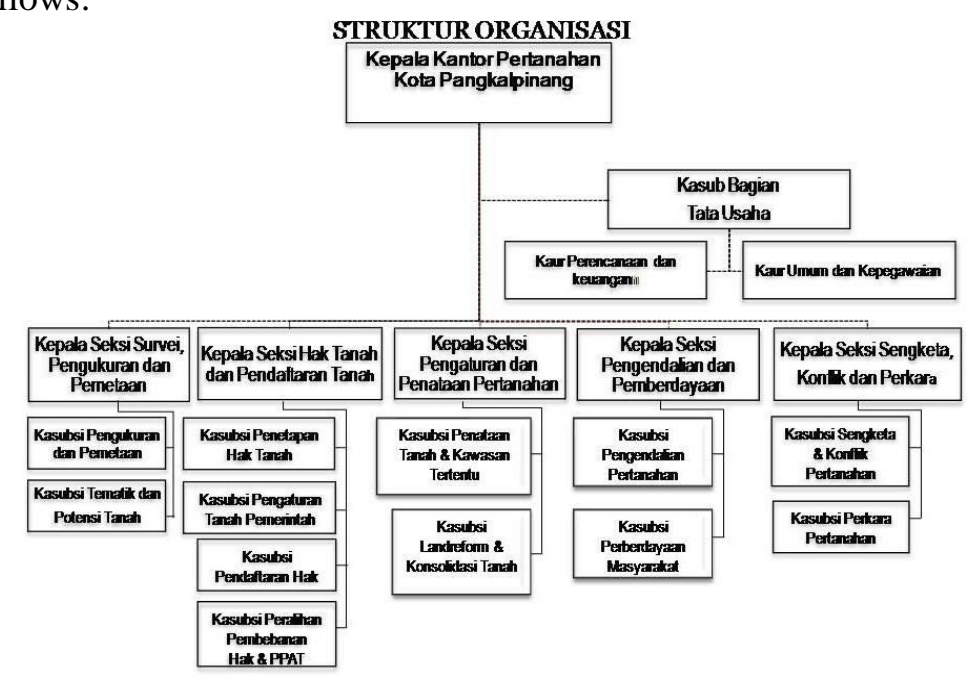

Figure 1 Pangkalpinang City Land Office Organization Structure Source: Pangkalpinang City Land Office

In carrying out its duties and work, the Pangkalpinang City Land Office has 45 employees that consist of 28 Civil Servants and 17 contract workers. The following is a list of employees at the Pangkal Pinang City Land Office based on employee status and position.

Table 1 Status and Position of Pangkalpinang City Land Office Employees

\begin{tabular}{|c|c|c|c|c|c|c|}
\hline \multirow[t]{2}{*}{ No. } & \multirow[t]{2}{*}{ Sub Division/Section } & \multicolumn{2}{|c|}{ Employee Status } & \multicolumn{3}{|c|}{ Employee Position } \\
\hline & & PNS & PTT & Eselon IV & Eselon V & Staff \\
\hline 1. & Administration Sub Division & 4 & 5 & 1 & 1 & 2 \\
\hline 2. & $\begin{array}{l}\text { Survey, Measurement and } \\
\text { Mapping }\end{array}$ & 9 & 3 & 1 & 2 & 9 \\
\hline 3. & $\begin{array}{l}\text { Land Rights and Land } \\
\text { Registration }\end{array}$ & 8 & 9 & 1 & 3 & 14 \\
\hline 4. & $\begin{array}{c}\text { Land Arrangement and } \\
\text { Arrangement }\end{array}$ & 2 & 0 & 1 & 1 & 0 \\
\hline 5. & Control and Empowerment & 2 & 0 & 1 & 1 & 0 \\
\hline 6. & Disputes, Conflicts and Cases & 3 & 0 & 1 & 2 & 0 \\
\hline & Total & 28 & 17 & 6 & 10 & 25 \\
\hline
\end{tabular}

Source: Pangkalpinang City Land Office 


\section{Rony Kurniawan}

The vision of the Pangkalpinang City Land Office is to become a Land Office that excels in land services. Therefore, it can make a valuable contribution to the wider community. The mission of the organization is a general formulation of the efforts and actions that will be carried out to realize the vision.

\section{B. Performance of the Pangkalpinang City Land Office}

Researchers analyzed the performance of the Pangkalpinang City Land Office in carrying out its duties and functions by using indicators of effectiveness, responsiveness and accountability (Hakim, 2014).

\section{Effectiveness}

The indicator of effectiveness is to measure and analyze the suitability of the policy with the implementation of tasks and work with the results achieved by the Land Office of Pangkalpinang City. For the targets and targets measured in effectiveness indicators, it refers to the policies that have been set by the Pangkalpinang City Land Office in providing services to the community. The public can find out the application files that must be completed along with the costs that must be paid to the state by asking the counter officer who is the front office officer.

Several types of services have been able to be completed correctly by the stipulated provisions, although many can be completed before the specified deadline (Hardiyansyah, 2018). It is necessary to find solutions and breakthroughs to overcome these problems by optimizing all available resources. It is also a must to be active from the applicant to complete the required files and resolve problems if there is a dispute in the land parcel.

\section{Responsiveness}

Here responsiveness means the organization's ability to recognize community needs, set service agendas and priorities, and develop public service programs under community needs and aspirations (Zauhar, 2015). All complaints, suggestions, and aspirations of the community regarding services of land administration have made the ingredients, namely a suggestion box placed in the counter room and instructing the counter officer to receive and record all suggestions and complaints submitted directly. A verbal complaint to a counter officer is an applicant who asks about the abandoned application. Besides, a written suggestion usually contains advice and opinions about the services available at the Land Office in general.

Then the Decree of the Head of BPN No.37/Kep-3.41/II/2014 was issued concerning the 2014 BPNRI Reform Quick Wins Program. The Quick Wins Program is a program to accelerate services to the community as one of the Bureaucratic Reform programs currently being intensively implemented by all ranks of BPN RI. The "Yuk Ning kek Kak Unan" program (Let's Improve Building Use Rights) is a follow-up to the Quick Win program that aims to provide acceleration in rights enhancement services. The program is more active in opening services by deploying Larasita-cars in housing estates residents whose most of the land parcels are still with Building Use Rights certificates.

The PASTI Program, which stands for Inter-Certificate Officer, is a program launched by the Pangkalpinang City Land Office that provides a delivery service for completed certificates to the elderly without being charged. An additional fee community land applications are following predetermined standards, even making breakthroughs to further accelerate and facilitate the community in obtaining the required land services.

3. Accountability

A public organization should be responsible for its policies and activities following the vision and mission of the organization as well as the prevailing norms in serving the interests of the community because the purpose of public organizations is to 
provide services to the community (Nawi, 2017).

It is based on the vision and mission of the Pangkalpinang City Land Office that aims to provide land services by increasing certification as one of the work programs that can be felt by the community and others. As a government agency that has to take care of land administration, the Pangkalpinang City Land Office must be able to take responsibility for the task of certifying land, which has not yet been fully implemented.

Article 19 of Law no. 5 of 1960 concerning Basic Regulations on Agrarian Principles states that land registration is carried out by the government taking into account the state and community conditions. It means that the government should carry out land registration activities including certifying unregistered all land parcels in Indonesia (Sibuea, 2016).

In Pangkalpinang City, with only a target of approximately 1000 plots of land per year that can be certified through PRONA, of course, there are still many parcels of land that have not been registered. Apart from PRONA, the community can independently certify their plots of land, of course at their own expense. It takes awareness from the community to want to certify their land parcels, because usually those who want to certify their land parcels for several reasons, including those who really want legal certainty over the plot of land or are pressed to want to make the plot of land as collateral for debts in the bank.

Currently, there is some inadequate stigma against land services, making people reluctant to come to the Land Office to take care of their needs. The existence of several requirements that must be completed in applying for land certificates still makes people confused and feels burdensome. Even though these requirements are mandatory requirements that should be done, the application can be processed at the Land Office, so that the legal certainty of the land parcel being applied for can be guaranteed. People who take shortcuts usually don't want to be bothered in fulfilling the requirements requested and want a certificate to be ready quickly, so they take advantage of the services of land brokers or land office employees to take care of it. That is what causes the cost of certification to be expensive and time-consuming and is considered convoluted. It can also be the reason why people are reluctant to certify their land parcels, although not all of the certificate-making processes are like that.

From the description above, it is known that there are still many uncertified lands in Pangkalpinang City due to several reasons as follows.

a. The limited state budget in carrying out land registration on community land parcels. Thus, the implementation of land certification through PRONA, PRODA, and other activities is determined to be limited in number per region per year.

b. Public awareness to certify their land is still low. They only want to certify their plots of land if they will sell it or there are other urgent needs.

c. There is a stigma circulating in the community that taking care of certificates is long, complicated, and expensive. Therefore, people are reluctant to certify their plots of land.

The Pangkalpinang City Land Office has a special strategy in designing its work program that adapted to the characteristics of the region. By optimizing all available resources, the Pangkalpinang City Land Office carries out all the targets and tasks contained in the Annual Work Plan which is prepared based on the Strategic Plan (RENSTRA), Budget Implementation List (DIPA), and Ministry/Agency Budget Work Plan (RKA-K). /L). Then there is the acceleration program for certification with the Larasita car that goes to the public, the Quick Wins program, the "Yuk Ning kek Kak Unan" program, and other acceleration programs. 


\section{Rony Kurniawan}

The performance of the Pangkalpinang City Land Office also received appreciation from the Ombudsman of the Republic of Indonesia regarding the level of compliance with Public Service Standards. As stated by the Head of the Ombudsmas RI Babel Representative, Jumli Jamaluddin that in 2015, the Ombudsman had taken a sample of 109 BPN offices throughout Indonesia and examined the level of compliance according to Law Number 25 of 2009 concerning Public Services.

By implementing its vision and mission into its policies and work programs quite well, the Land Office of Pangkalpinang City can achieve physical targets as well as the planned budget absorption and take into account the community and people's representatives through tiered reporting. It can be seen that from the performance accountability indicators of the Land Office of Pangkalpinang City has been running well. However, the performance indicators show that there is data on services to the community that has not been implemented optimally in terms of completion time according to Service Standards and Land Regulations.

\section{Factors that Inhibit and Support the Performance of the Pangkalpinang City Land Office}

Among many factors described by experts, the researchers chose three factors that are considered to affect office performance, namely:

1. Employee Ability

Robbins in (Hidayati, 2019) defines ability as an individual's capacity to do various tasks in a job. The overall abilities of an individual are essentially composed of two sets of factors: intellectual abilities and physical abilities. So that the employee's ability here is the capacity or ability of the employee that includes the physical and intellectual abilities used to do and complete all office work assigned to him. The ability of employees here can be seen from the physical and intellectual side of the employee. The data below can explain the physical data owned by the Pangkalpinang City Land Office employee, which affects his ability to work.

Table 2 Data on Employee Gender and Age

\begin{tabular}{ccccccc}
\hline No. & Sub Division/Section & Total & \multicolumn{2}{c}{ Gender } & \multicolumn{2}{c}{ Age (Year) } \\
\hline & Employee & Male & Female & $>35$ & $<35$ \\
\hline 1 & $\begin{array}{c}\text { Administration Sub } \\
\text { Division }\end{array}$ & 9 & 4 & 5 & 4 & 5 \\
\hline 2 & $\begin{array}{c}\text { Survey, Measurement and } \\
\text { Mapping }\end{array}$ & 12 & 9 & 3 & 2 & 10 \\
\hline 3 & $\begin{array}{c}\text { Land Rights and Land } \\
\text { Registration }\end{array}$ & 17 & 12 & 5 & 7 & 10 \\
\hline 4 & $\begin{array}{c}\text { Land Arrangement and } \\
\text { Arrangement }\end{array}$ & 2 & 1 & 1 & 0 & 2 \\
\hline 5 & $\begin{array}{c}\text { Control and Empowerment } \\
\quad\end{array}$ & 2 & 1 & 1 & 1 & 1 \\
\hline 6 & Disputes, Conflicts and \\
Cases & 3 & 1 & 2 & 1 & 2 \\
\hline & Total & 45 & 28 & 17 & 15 & 30
\end{tabular}

Source: Pangkalpinang City Land Office 


\section{Eduvest - Journal of Universal Studies \\ Volume 1 Number 8, August 2021}

By increasing intellectual abilities in using software and other work equipment, employers are expected to work faster and reduce the use of physical energy at work. That is technological progress that helps human work, although in the future maybe the use of human physical energy can be reduced to be replaced by sophisticated tools. Therefore, good intellectual abilities must be possessed by employees of the Pangkalpinang City Land Office to be able to take advantage of technological advances to replace the limited number of employees and physical abilities that may be inadequate.

\section{Employee Motivation}

Motivation is the desire to do as a willingness to spend a high level of effort for organizational goals, which depends on the ability of that effort to meet an individual need. Motivation arises from within the employee that is connected between the need to earn a living to meet his needs and the choice in choosing a profession. As a vertical agency, employees can be placed in BPN in all work units throughout the territory of Indonesia. When he was positioned back in his hometown, the employee considered this an injection of enthusiasm and motivation to work because he could be close to his family and parents and according to his expectations to be able to work and build his hometown.

From the description above, it is following what was stated by Robbins that motivation is the desire to do as a willingness to spend a high level of effort for organizational goals can affect motivation, but motivation itself reflects the individual's reaction to these stimuli.

\section{Community Participation}

Community participation or support is an external factor that supports the performance of the Pangkalpinang City Land Office. It is for the development and implementation of public services as carried out by the Pangkalpinang City Land Office. One of the supports that can be seen from the community is the applications in managing correspondence and certificates of land parcels they have. Ensuring the implementation of land registration which is the duty of the state, the government through the National Land Agency carries out mass certification annually where all costs are financed by the state. Public interest in participating in this program in several urban villages looks very good, especially those who do not have the money but want the land has a certificate. Community participation in some villages is still minimal and does not care about the processes involved in PRONA activities. They assume that after registering as a PRONA participant and submitting documents, BPN must make it a certificate.

The less active attitude towards existing problems and reliance on all solutions to BPN will make it more difficult and longer to complete the application file. Thus, public participation is needed by a public organization in carrying out its duties in providing services the public is to provide information and socialize. Increasing public participation in supporting the performance of the Land Office is not easy because it is a factor that comes from outside the organization (Masirun, 2016). Of course, there must be tips and breakthroughs from the Pangkalpinang City Land Office to continue to provide understanding and counseling to the public about the importance of certificates as proof of legality of ownership of the land.

\section{CONCLUSION}

From the results, it can be concluded that the performance of the Pangkalpinang City Land Office, in general, has been able to run well and has met the expectations of the community in serving most of the land administration activities carried out by the 


\section{Rony Kurniawan}

community. The indicators are effectiveness, responsiveness, and accountability. The effectiveness measured and analyzed the suitability between policies and the implementation of tasks and work with the results achieved by the Pangkalpinang City Land Office, that most of the work and requests from the community can be completed properly and following the service standards that have been set. Responsiveness is in the form of that Pangkalpinang City Land Office is good at recognizing and knowing the community needs by running and launching acceleration programs such as the Quick Wins program, Yuk Ning kek Kak Unan, PASTI, and other programs. Accountability is based on the Land Office of Pangkalpinang City in carrying out its duties and functions by following the vision and mission of the organization as reflected in the achievement of targets that have been prepared in the Annual Work Plan.

Internal and external factors that influence the performance of the Pangkalpinang City Land Office are as follows: The ability of employees is an internal factor that is considered sufficient in supporting the performance of the Office but must be improved, especially the intellectual abilities of employees. Motivation is also an internal factor that looks very good but still must be raised continuously by each employee, and it becomes the task of superiors, be it the head of the office or the head of the section. Community participation is an external factor that is deemed less supportive of the Office's performance because it can be seen that participation in independent certificate making is still not too much. The existence of other external factors found by the author can affect the performance of the Pangkalpinang City Land Office, namely the communication factor.

\section{REFERENCES}

Adolf, J. (2017). Pelaksanaan Tugas Dan Fungsi Pejabat Pembuat Akta Tanah Dalam Peralihan Hak Milik Atas Tanah Karena Jual Beli Untuk Memberikan Kepastian Hukum Di Kota Pangkalpinang Provinsi Bangka Belitung (The Implementation of the Duties and Functions of Land Deed Making Officials in the Transfer of Land Ownership as Sale and Purchase to Provide Legal Certainty in Pangkalpinang City, Bangka Belitung Province). UAJY.

Afriani, B. (2018). Penyelesaian Sengketa Tumpang Tindih Hak Antara Sertipikat Hak Milik (SHM) dengan Surat Keterangan Tanah (SKT) di Kota Pangkalpinang (Settlement of Overlapping Rights Disputes between Property Rights Certificates (SHM) and Land Certificates (SKT) in Pangkalpinang). Universitas Bangka Belitung.

Hakim, A. (2014). Akuntabilitas kinerja aparatur pemerintah desa dalam pelayanan publik di Desa Tandam Hulu II Kecamatan Hamparan Perak Kabupaten Deli Serdang (Accountability of local government officials performance in public services in Tandam Hulu II Village, Hamparan Perak District, Deli Serdang Regency). Jurnal Administrasi Publik: Public Administration Journal, 4(1), 1-20.

Hardiyansyah. (2018). Kualitas Pelayanan Publik: Konsep, Dimensi, Indikator dan Implementasinya (Quality of Public Services: Concepts, Dimensions, Indicators and the Implementation). Gava Media.

Hidayati, N. N. (2019). Pengaruh Budaya Organisasi Terhadap Kinerja Karyawan Dengan Komitmen Organisasi sebagai Variabel Intervening pada PT. Citra Perdana Kendedes (The Influence of Organizational Culture on Employee Performance with Organizational Commitment as an Intervening Variable at PT. Citra Perdana Kendedes). University of Muhammadiyah Malang.

Juniati, A.A.A. (2012). Analisis Kinerja Pengelolaan Kearsipan Badan Perpustakaan 
Arsip dan Dokumentasi Kota Denpasar (Archiving Management Performance Analysis of the Denpasar City Archives and Documentation Library). Denpasar: Universitas.

Kurniati, Y.I. (2012). Analisis Kinerja Pelayanan Publik Aparatur Pemerintah Pada Kantor Camat Labuhan Badas kecamatan Labuhan Badas kabupaten Sumbawa Provinsi Nusa Tenggara Barat (Analysis of Public Service Performance of Government Apparatus at the Labuhan Badas Sub-district Office, Labuhan Badas District, Sumbawa Regency, West Nusa Tenggara Province). Program Pascasarjana Universitas Terbuka Jakarta.

Maharani, L.P. (2021). Problematika Pencatatan dan Peralihan Hak atas Harta Bersama Suami Isteri (Problems of Registration and Transfer of Rights Joint Property of Husband and Wife)(Studi di Kantor Pertanahan Kota Pangkalpinang Provinsi Kepulauan Bangka Belitung/A Study at the Land Office of Pangkalpinang City, Bangka Belitung Islands Province). Sekolah Tinggi Pertanahan Nasional.

Masirun. (2016). Analisis kinerja pegawai pada Kantor Pertanahan Kota Pekanbaru (Pada seksi Hak Tanah dan Pendaftaran Tanah) (Analysis of employee performance at the Pekanbaru City Land Office (In the section on Land Rights and Land Registration)). Jurnal Ilmiah Ekonomi Dan Bisnis Unilak, 13(1), 96425.

Nawi, H.R. (2017). Perilaku Kebijakan Organisasi (Organizational Policy Behavior) (Vol. 1). SAH MEDIA.

Sibuea, H.Y.P. (2016). Arti penting pendaftaran tanah untuk pertama kali (The importance of first time-registering land). Negara Hukum: Membangun Hukum Untuk Keadilan Dan Kesejahteraan, 2(2), 287-306.

Singarimbun, M. and Effendi, S. (1989). Metode Penelitian Survei, Jakarta.

Sukowati, K. (2010). Kinerja Organisasi Kantor Kecamatan Kedawung Kabupaten Sragen (Organizational Performance of Kedawung District Office, Sragen Regency). UNS (Sebelas Maret University).

Wijayanto, G. (2011). Komitmen Pegawai dan Budaya Organisasi pada Kinerja Pegawai (Employee commitment and organizational culture on employee performance). JIANA (Jurnal Ilmu Administrasi Negara), 11(2).

Zauhar, S. (2015). Kinerja dinas kependudukan dan catatan sipil dalam pelayanan administrasi kependudukan di kabupaten Kotabaru Kalimantan selatan (The performance of the population and civil registry services in population administration services in Kotabaru Regency, South Kalimantan). JISIP: Jurnal Ilmu Sosial Dan Ilmu Politik, 4(3). 